\title{
OBITUARY.
}

\section{EDWARD P. FROST, J.P., D.L.}

One more link with the past has gone in the death on 26th January of Mr. Edward Purkis Frost, one of the oldest pioneers of aviation. Born in 1842 , he early became interested in the subject of flight and his name first appears in the list of members of the Aeronautical Society in 1875 . In 1880 he was elected to the Council and became President of the Society in 1908. Among the old "Reports" of the Society his name frequently appears, and in $188_{3}$ he read a paper on "Aeronautics, with remarks on a visit to the Aeronautical Exhibition in Paris." In the 23 rd Report is another paper by him referring to his experiments on feathers.

As a typical country squire, rather than the scientific engineer, Mr. Frost was ever watching the flight of birds and critically examining their wings. Insects and even winged seeds were also objects of his close study. Living in one of the finest partridge districts in England, Six-Mile Bottom, in Cambridgeshire, he was a keen shot and had every opportunity for studying the flight of these and other birds. The structure of the feather was his special problem. From small models of artificial feathers he evolved larger ones till he made some of $\mathrm{I} 4$ feet long, one of which was exhibited at a meeting of the Society in $189 \mathrm{I}$. The main rib being on one side of the central axis, when the feather was beaten downwards, with ever so great an effort it always slipped away to the side, showing the propulsive force of a natural wing beat.

This led him to the construction of a full-sized flying machine of the " ornithopter" or beating-wing type, which took him ten years to build. It was originally supposed to be an exact imitation of a crow, though as eventually carried out it became very different, having supplementary aeroplanes and other features. It had a span of 30 feet to wing tip and was composed of 80 large artificial feathers. It was to be actuated by a steam engine, the whole weight, including engine and boiler, being 65olbs. But great difficulties were experienced with the engine, which did not develop so great a power as was anticipated, and the machine remained for many years merely as a monument of patient endeavour.

In $1902 \mathrm{Mr}$. Frost started on another series of experiments, in conjunction with Dr. Hutchinson and Mr. D'Esterre. These were described and illustrated in the Akronatrical Jocknal for July, rgoz. The larger model consisted of a pair of wings, 20 feet across, actuated by a $3 \mathrm{~h} . \mathrm{p}$. petrol engine. These were mounted on a light steel framework on wheels, and were arranged to flap roo times a minute.

King Edward, when Prince of Wales, showed much interest in Mr. Frost's experiments, and during his shooting expeditions to the neighbourhood visited the sheds and workshops.

Mr. Frost, among many other interests, made a study of the subject of universal peace, and wrote an interesting book, entitled, "Safeguards for Peace: A Scheme of State Insurance Against War," published in rgo5.

To his friends he will ever be remembered as a courteous gentleman of the old school, enthusiastic on his hobbies, and ever ready to assist the cause of aeronautics in an unselfish and retiring manner.

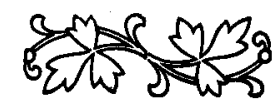

